\title{
Optimization of lipase production by Aspergillus ibericus from oil cakes and its application in esterification reactions
}

\author{
Felisbela Oliveira ${ }^{a}$, Carlos E. Souza $^{b}$, Verônica R.O.L. Peclat ${ }^{b}$, José Manuel \\ Salgado $^{a}$, Bernardo D. Ribeiro ${ }^{b}$, Maria A.Z. Coelho ${ }^{b}$, Armando Venâncio $^{a}$, \\ Isabel Belo ${ }^{a, *}$
}

${ }^{a}$ CEB-Centre of Biological Engineering, University of Minho, 4710-057 Braga, Portugal

$\mathrm{b}$ Biochemical Engineering Department, Federal University of Rio de Janeiro, Rio de Janeiro, Brazil

\section{A R T I C L E I N F O}

Article history:

Received 19 September 2016

Received in revised form 21

December 2016

Accepted 11 January 2017

Available online 20 January 2017

\section{Keywords:}

Palm kernel oil cake

Sesame oil cake

Solid-state fermentation

A. ibericus

Lipase production

Aroma esters production

\begin{abstract}
A B S T R A C T
Due to the actual emphasis in revalorization of agro-industrial wastes and cost reduction of enzymes production, this work aimed the optimization of lipase production from different oil cakes (OCs) produced in Brazil, by solid-state fermentation using Aspergillus ibericus MUM 03.49 and the application of the produced lipase in hydrolysis and esterification reactions. Higher lipase production was obtained using palm kernel oil cake (PKOC), yielding $127 \pm 17 \mathrm{U} / \mathrm{g}$ of lipase (per mass of dry substrate). Through SSF optimization, using PKOC mixed with sesame oil cake (SOC) in a ratio of $0.45 \mathrm{~g}$ of PKOC per $\mathrm{g}$ total substrate at $57 \%$ moisture content $(\mathrm{MC})$, a production of $460 \pm 38 \mathrm{U} / \mathrm{g}$ of lipase was obtained after 6 days of fermentation. The obtained lipase was used in hydrolysis reactions, where it was observed higher production in short-chain triacylglycerols (TAGs) substrates. Also, it was applied in esterification reactions, where the formation of butyl decanoate using $5 \%(\mathrm{w} / \mathrm{v})$ of biocatalyst was the most efficient. SSF of PKOC and SOC is a low cost competitive process to obtain A. ibericus lipase that can be used in aroma esters production, with application in the food industry.
\end{abstract}

๑ 2017 Institution of Chemical Engineers. Published by Elsevier B.V. All rights reserved.

\section{Introduction}

Oil cakes (OCs) are agro-industrial by-products obtained after oil extraction from seeds (Ramachandran et al., 2007). Their composition varies depending in their variety, growing conditions and extraction methods and can be classified as edible or non-edible oil cakes (Singhania et al., 2008). The main application of OCs is as animal feed due to their high protein content. They have been used as feed in poultry, fish and swine industry (Singhania et al., 2008). However, several OCs have low protein content and are considered non-edible oil cakes. Thus, OCs can be used in other applications, such as the production of antibiotics and biopesticides (Kota and Sridhar, 1999; Sircar et al., 1998) and other biochemicals (Ohtsuki et al., 2003), in the production of mushrooms (Bano et al., 1993), as a bio-control agent (Khan and Saxena, 1997),

\footnotetext{
* Corresponding author. Fax: +351253604429 .

E-mail address: ibelo@deb.uminho.pt (I. Belo).
} http://dx.doi.org/10.1016/j.fbp.2017.01.007

0960-3085/@ 2017 Institution of Chemical Engineers. Published by Elsevier B.V. All rights reserved. and can also be used for energy production (Atimtay and Topal, 2004). Other alternative for the use of OCs is in biotechnological processes to obtain added-value products. OCs are a good source of carbon, nitrogen and other compounds (Ramachandran et al., 2007). Thus, they are considered good substrates for fermentation processes as solid-state fermentation (SSF).

SSF is a fermentation process involving the cultivation of microorganisms on moist solid substrate (Pandey, 2003). SSF is a technique of special economic interest for countries with abundant biomass and agro-industrial residues, as these can be used as cheap raw materials (Gombert et al., 1999). Besides this, the technology involved in those processes is simple and cheap, comparing to submerged fermentation (SmF) (Castilho et al., 2000). SSF has been particularly suitable for the production of enzymes by filamentous fungi, since it reproduces the natural living conditions of low water activity adequate of such fungi (Couto and Sanromán, 2005). This is apparently the main factor why they perform well and give higher products yields in SSF when compared with SmF (Thomas et al., 2013). Several filamentous fungi species 
have been used in SSF applications among which Aspergillus species have been reported as very efficient for different enzymes production (Serra et al., 2006). Aspergillus ibericus is a fungus isolated from wine grapes from Portugal and Spain. It was identified as a new species from section Nigri and does not produce mycotoxins (Serra et al., 2006). Previous studies reported its ability to produce lignocellulosic enzymes, such as cellulases, xylanases and feruloyl esterases (Salgado et al., 2014a), and also, to produce lipase by SmF using olive mill wastewater (Abrunhosa et al., 2013), and by SSF using olive pomace (Oliveira et al., 2016, 2015a,b; Salgado et al., 2014b). Similarly to the agro-industrial residues from olive oil industry, OCs presents residual content of lipids which can be applied for lipase production by SSF, since induces lipase synthesis (Edwinoliver et al., 2010; Gombert et al., 1999; Kamini et al., 1998; Mala et al., 2007).

Lipases (triacylglycerol acylhydrolases, EC 3.1.1.3) are efficient biocatalysts in esterification, interesterification and transesterification reactions in non-aqueous media (organic solvents and supercritical fluids). In addition, they catalyze alcoholysis, acidolysis and aminolysis reactions, as well as hydrolyze organic carbonates (Joseph et al., 2008; Salihu et al., 2012). For this reason lipases are widely used in industry, with applications in industry of food, fine chemicals, detergent, waste water treatment, cosmetics, pharmaceuticals, leather processing and in biomedical assays (Salihu et al., 2012). Lipases also can be applied in the field of bioenergy, especially in biodiesel production (Salihu et al., 2012). The last decade, increasing attention has been paid to the agroindustrial residues processing by SSF to obtain lipases with different applications (Couto and Sanromán, 2005), such as in the production of aroma esters, in a solvent-free system, which is of much commercial interest with the increasing demand of consumers for natural products (Ben Salah et al., 2007). Also, considering the scaling-up process, enzymatic esterification in a solvent-free system presents advantages, such as savings in reactor design for large-scale process and reduction in separation costs by avoiding solvent recovery costs (Bezbradica et al., 2007).

The aim of this work was to screen OCs from Brazil to optimize lipase production by A. ibericus MUM 03.49, and to study the effect of OCs composition on lipase production. The lipase produced was used in hydrolysis reactions to measure its activity in different substrates, triacylglycerols (TAGs) and olive oil; and also it was applied in enzymatic esterification reactions, in a solvent-free system, for the production of aroma esters

\section{Material and methods}

\subsection{Biological material}

A. ibericus MUM 03.49 (MUM culture collection, Braga, Portugal) was used. It was revived on malt extract agar (MEA) plates $(2 \%(\mathrm{w} / \mathrm{v})$ malt extract, $2 \%(\mathrm{w} / \mathrm{v})$ glucose, $0.1 \%(\mathrm{w} / \mathrm{v})$ peptone and $2 \%(\mathrm{w} / \mathrm{v})$ agar) from a frozen glycerol stock. A spore suspension was prepared by adding peptone solution $(0.1 \%(\mathrm{w} / \mathrm{v})$ peptone and $0.01 \%(\mathrm{w} / \mathrm{v})$ Tween 80 ) to seven-day-grown culture plates at $30^{\circ} \mathrm{C}$. The spore concentration of the suspension was adjusted to $10^{7}$ spores $/ \mathrm{mL}$.

\subsection{OCs used as substrates}

Several different oil cakes (OCs) were used. They were collected during the season 2013/2014 and were obtained from different suppliers, such as: Andiroba oil cake (AOC) and cupuassu oil cake (CuOC) obtained from Beraca Ingredientes Naturais S.A. (São Paulo); canola oil cake (CaOC), macauba oil cake (MOC), palm kernel oil cake (PKOC) and soybean meal (SBM) from CENPES/PETROBRAS (Rio de Janeiro); crambe oil cake (CrOC), green coffee oil cake (GCOC) and sesame oil cake (SOC) from CRODA do Brasil, S.A. (Campinas-São Paulo). OCs were ground and sieved to provide a particle size $\leq 1.19 \mathrm{~mm}$.

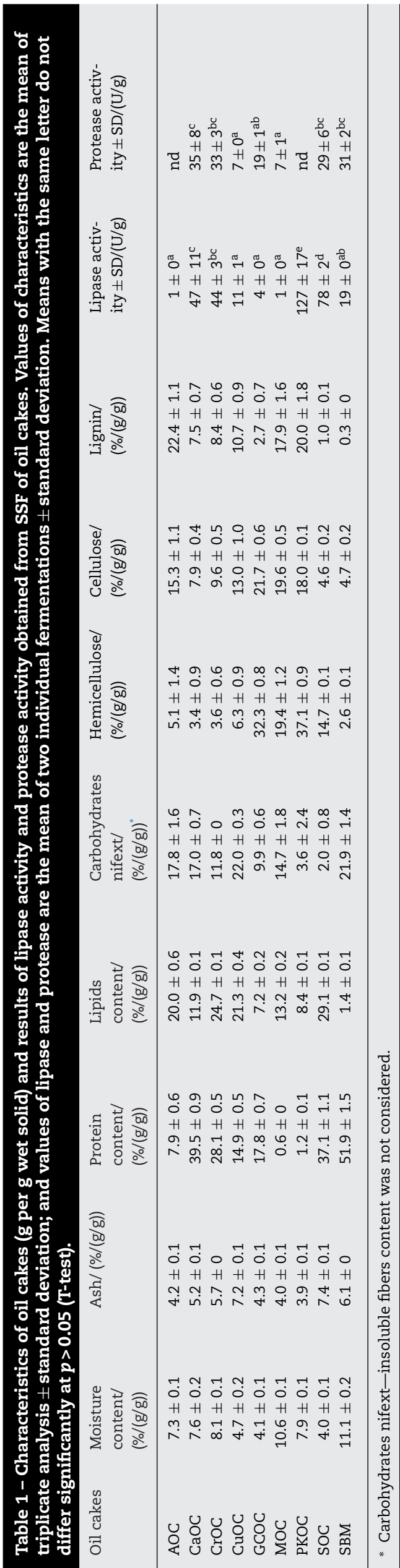




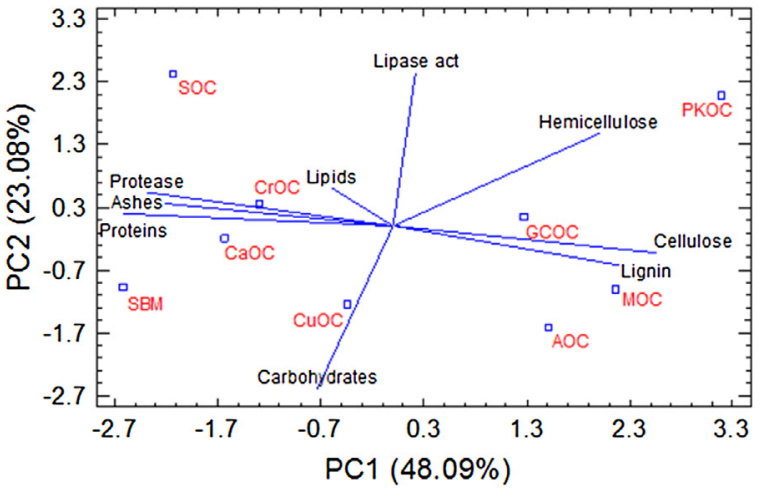

Fig. 1 - Biplot representation of variables and scores of the oil cakes (OCs).

The characteristics of the substrates were determined according to the literature (AOAC, 1995; IAL, 2005; Mendez et al., 1985; Van Soest, 1963). MC was determined by drying the oil cake at $105^{\circ} \mathrm{C}$, ash by incineration of samples at $500-550^{\circ} \mathrm{C}$, and lipids content by Soxhlet method (AOAC, 1995; IAL, 2005). Protein content was determined by Micro-Kjeldahl method, using a factor of 6.25 to convert $\mathrm{N}$ to protein (AOAC, 1995). Carbohydrates nifext were determined by the subtraction of a hundred to the sum of MC, ash, lipids, protein and insoluble fiber, according to the legislation RCD 360/2003; and thus insoluble fiber content was not considered for the carbohydrates content. The determination of hemicellulose, cellulose and lignin was performed by determination of acid detergent fiber (ADF) and neutral detergent fiber (NDF) measurements, after extraction with acid detergent and neutral detergent, according to the procedures described by Van Soest (1963) and Mendez et al. (1985), respectively, using a six-plate setup for Dosi-fiber extraction (Tecnal). Lignin and cellulose was determined by using hydrolysis solution, according to Van Soest (1963), cellulose was determined by subtraction of lignin to ADF; and hemicellulose was determined by the subtraction of ADF (sum of cellulose and lignin) to NDF (sum of cellulose, hemicellulose and lignin). The analyses were performed in triplicate.

\subsection{SSF of OCs for lipase production}

SSFs were carried out using cotton-plugged $250 \mathrm{~mL}$ Erlenmeyer flasks containing $15 \mathrm{~g}$ of dry solid substrate. The MC was adjusted to $60 \%$ (wet basis) by adding distilled water. Flasks were autoclaved at $121^{\circ} \mathrm{C}$ for $15 \mathrm{~min}$, cooled and inoculated with $0.5 \mathrm{~mL}$ of $10^{7}$ spores $/ \mathrm{mL}$ of spore suspension. Flasks were incubated at $30^{\circ} \mathrm{C}$ for 7 days. All fermentations were performed in duplicated flasks.

\subsubsection{SSF with combination of OCs}

Mixtures of the best OCs selected were used in SSF. PKOC was combined in a ratio of $1: 1(\mathrm{w} / \mathrm{w})$ with CrOC and SOC. Fermentations were carried out using $7.5 \mathrm{~g}$ of each OC mixed with $7.5 \mathrm{~g}$ of PKOC, with the MC adjusted to $60 \%$, keeping other conditions as previously described.

\subsubsection{Influence of substrate ratio and $\mathrm{MC}$ on lipase production}

The best mixture of OCs identified was further explored using an experimental design for optimization of lipase production. The program Statistica 7 software (StatSoft, Tulsa, USA) was used to plan and analyze a central composite design, with two factors and two levels with additional star points. MC ranged from $50 \%$ to $70 \%$, and the ratio of PKOC (RPKOC) in the substrate mixture (PKOC and SOC), expressed as $g$ of PKOC per $g$ of total substrate, ranged from 0.25 to $0.75 \mathrm{~g} / \mathrm{g}$ of total substrate. The central point was performed in triplicate.

The relationship between the dependent (lipase activity) and independent (MC and RPKOC) variables was established by the polynomial equation, as follows:

$y=a_{0}+a_{1} x_{1}+a_{2} x_{2}+a_{11} x_{1}^{2}+a_{22} x_{2}^{2}+a_{12} x_{1} x_{2}$

where $y$ is the predicted response, $x_{1}$ and $x_{2}$ are independent variables, $a_{0}$ is the model constant, $a_{1}$ and $a_{2}$ are linear coefficients, $a_{11}$ and $a_{22}$ are the quadratic coefficients and $a_{12}$ is the interaction coefficient. The statistical analysis was performed by Statistica 7 software and the maximum lipase activity was determined by the Solver tool of Microsoft Excel 2010.

\subsubsection{Supplementation with nitrogen source}

SSF were performed with addition of $\mathrm{NH}_{4} \mathrm{Cl}$, in order to supplement the substrates with a nitrogen source. Concentrations of $\mathrm{NH}_{4} \mathrm{Cl}$ ranged from $0 \%$ to $5 \%(\mathrm{w} / \mathrm{w})$ of $\mathrm{NH}_{4} \mathrm{Cl}$ mass per dry mass of solid OC.

\subsubsection{Time course profile of lipase production}

Finally, a time course profile of lipase production and productivity was performed using the optimum SSF conditions determined in the optimization experiment. Flasks were prepared as described before and destructively sampled each 2 days over a period of 20 days.

\subsection{Enzyme extraction and determination}

At the end of the incubation period, enzymes were extracted by adding $112.5 \mathrm{~mL}$ of $1 \%(\mathrm{w} / \mathrm{v})$ Triton X-100 (7.5 mL/g dry solid substrate) to the fermented substrates and mixed at $250 \mathrm{rpm}$ and $25^{\circ} \mathrm{C}$ for $30 \mathrm{~min}$. Mixtures were then centrifuged $(12000 \times \mathrm{g}$ for $10 \mathrm{~min}$ at $4^{\circ} \mathrm{C}$ ) and filtered using Whatman No. 1 filter paper. The resulting enzymatic extracts were immediately used for lipase and protease determination.

Lipase activity was determined by a spectrophotometric method, using a reaction mixture composed of $5 \mu \mathrm{L}$ of sample and $300 \mu \mathrm{L}$ of $2 \mathrm{mM} p$-nitrophenyl butyrate in potassium phosphate $50 \mathrm{mM}$ at $\mathrm{pH}$ 7.0. The absorbance was measured at $405 \mathrm{~nm}$ after reaction during $15 \mathrm{~min}$ at $37^{\circ} \mathrm{C}$. One unit of lipase activity $(\mathrm{U})$ was expressed as the amount of enzyme that produced $1 \mu \mathrm{mol}$ of $p$-nitrophenol per minute, under the assay conditions. The analyses were performed in triplicate. Lipase activity obtained was expressed as units per gram of dry solid substrate (U/g).

Protease was determined according to the method of Charney and Tomarelli (1947), using azocasein as the substrate. One unit of protease activity (U) was expressed as an increase in absorbance of 0.01 in relation to the blank per minute, under the assay conditions. The analyses were performed in duplicate. Protease activity was expressed as units per gram of dry solid substrate (U/g).

\subsection{Lipase activity in different substrates and application in esterification reactions}

\subsubsection{Lipolytic activity in different substrates}

Lipase produced was determined in several substrates. Olive oil and synthetic triacylglycerols (TAGs) such as glyceryl tribu- 

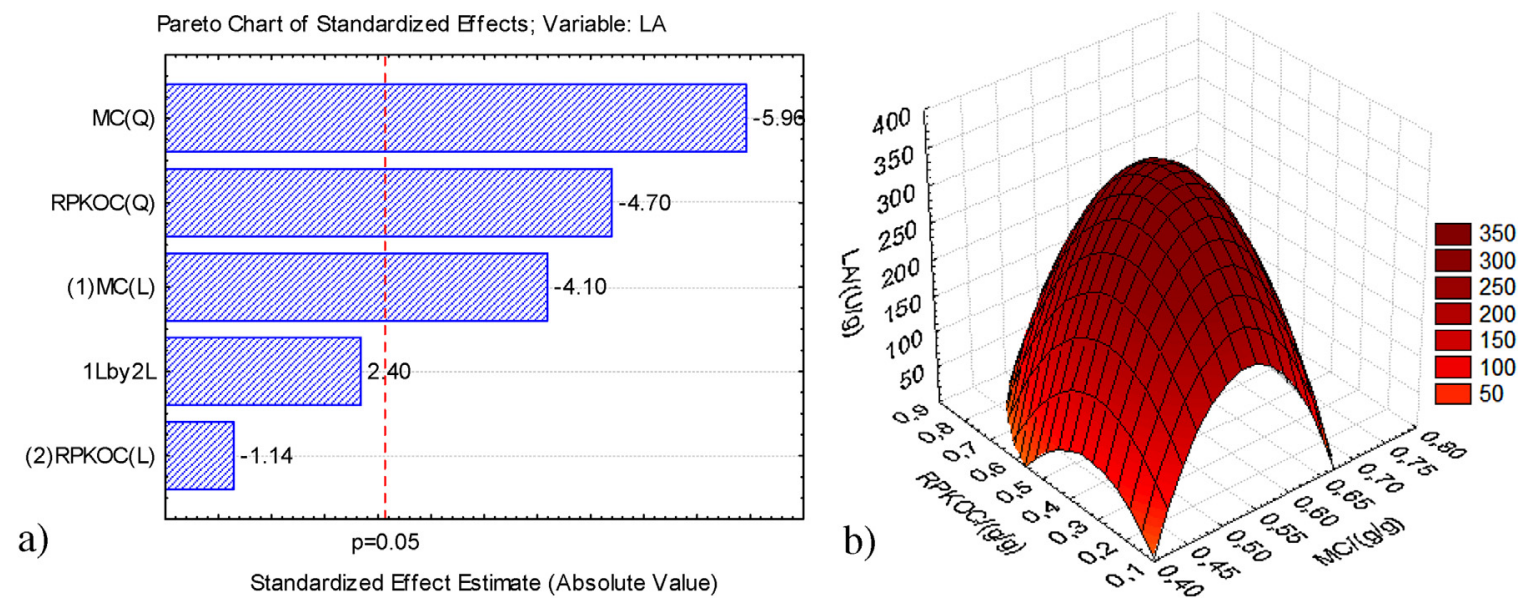

Fig. 2 - (a) Pareto chart of standardized effects of independent variables linear (L) and quadratic (Q), moisture content (MC) and PKOC ratio (RPKOC), expressed as g of PKOC per $g$ of total substrate, on lipase activity (LA). (b) Response surface of LA as a function of MC and RPKOC, according to Eq. (2).

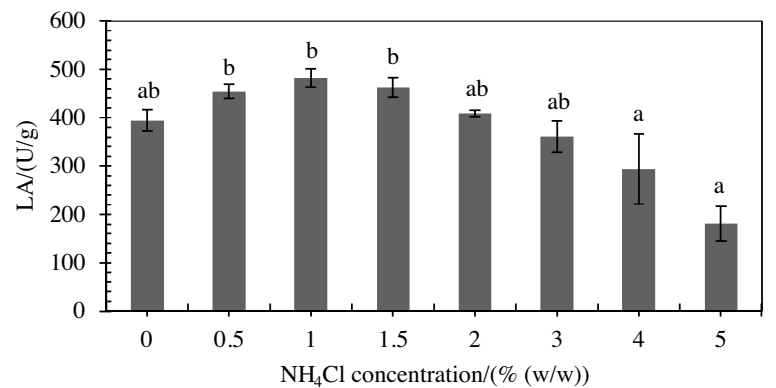

Fig. 3 - Results of lipase activity (LA) influenced by the $\mathrm{NH}_{4} \mathrm{Cl}$ concentration. Values are the mean of two individual fermentations \pm standard deviation. Means with the same letter do not differ significantly at $p>0.05$ (T-test).

tyrate (C4:0), glyceryl trioctanoate (C8:0), glyceryl tridecanoate (C10:0), glyceryl tripalmitate (C12:0) and glyceryl triesterate (C18:0) in $0.01 \mathrm{M}$ potassium phosphate buffer $\mathrm{pH} 7.0$ were used. The hydrolysis reaction occurred at $37^{\circ} \mathrm{C}$ for $20 \mathrm{~min}$, at which time it was interrupted by the addition of $1: 1(\mathrm{v} / \mathrm{v})$ acetone:ethanol mixture (1:1 v/v). Lipolytic activity was determined by titration of free fatty acids (FFAs) released with a pH-stat (916 Ti-Touch-Metrohm) using $0.04 \mathrm{M} \mathrm{NaOH}$ up to a final pH of 11, according to the methods of Freire et al. (1997) for olive oil, and Gutarra et al. (2009) for the synthetic TAGs. One unit of lipase activity $(\mathrm{U})$ was expressed as the amount of enzyme which released $1 \mu \mathrm{mol}$ of FFAs per minute, under the assay conditions. The analyses were performed in duplicate. Lipase activity obtained was expressed as units per gram of dry solid substrate $(\mathrm{U} / \mathrm{g})$.

\subsubsection{Esterification reactions catalyzed by lipase}

Esterification reactions were performed using different organic acids and alcohols. The mixture used was a 1:1 molar ratio of organic acid to alcohol in a total volume of $5 \mathrm{~mL}$. Lipase used was obtained from a 7 day SSF conducted under optimum conditions, with the fermented substrate containing the lipase simply being lyophilized. Reactions occurred in $15 \mathrm{~mL}$ falcon tubes with a $5 \mathrm{~mL}$ mixture of organic acid and alcohol in a $1: 1$ molar ratio, and $20 \%(\mathrm{w} / \mathrm{v})$ of biocatalyst was added to the mixture. The Falcon tubes were incubated in a shaker at $200 \mathrm{rpm}$ and $37^{\circ} \mathrm{C}$ for $24 \mathrm{~h}$, at which time $5 \mathrm{~mL}$ of $1: 1(\mathrm{v} / \mathrm{v})$ acetone with absolute ethanol was added. Conversion (\%) of the organic acid to ester was determined by titration of the remaining organic acid with $0.1 \mathrm{M} \mathrm{NaOH}$ until a pH equal to the $\mathrm{pK}_{\mathrm{a}}$ of the organic acid used. Esterification reactions were performed in duplicate.

Initially, different organic acids and alcohols were used. Combinations of lactic acid, butyric acid, propionic acid, hexanoic acid and decanoic acid with butanol were tested. Also, combinations of butyric acid with isobutanol, amyl alcohol, benzyl alcohol and menthol were tested.

Since decanoic acid with butanol presented the highest conversion (100\%), this combination was used in further studies. The minimum lipase concentration needed to achieve $100 \%$ of conversion in $24 \mathrm{~h}$ was determined. For that, $20 \%(\mathrm{w} / \mathrm{v})$, $10 \%, 5 \%$ and $1 \%$ of biocatalyst was used.

Using $10 \%(\mathrm{w} / \mathrm{v})$ of biocatalyst, a time course profile of conversion over reaction time was obtained.

Finally, the effect of adding a buffer to the biocatalyst, in esterification reaction was studied. For that, a low amount of lyophilized biocatalyst, $5 \%(\mathrm{w} / \mathrm{v})$, was added to Eppendorf tubes and ressuspended in $1 \mathrm{~mL}$ of Britton Robinson universal buffer $\left(0.04 \mathrm{M} \mathrm{H}_{3} \mathrm{BO}_{3}, 0.04 \mathrm{M} \mathrm{H}_{3} \mathrm{PO}_{4}, 0.04 \mathrm{M} \mathrm{CH}_{3} \mathrm{COOH}\right.$ and $0.2 \mathrm{M} \mathrm{NaOH})$ at $\mathrm{pH}$ values of $5-9$, and lyophilized again. The performance of this biocatalyst was subsequently analyzed in the reaction of decanoic acid with butanol.

\subsection{Statistical treatment}

Principal components analyses (PCA) were conducted with Statgraphics Plus 5.1 (Manusgistics, Inc., Rockville, MD) to determine how the variation in the composition of the residues affected enzymes production.

SSF data obtained were statistically analysed using SPSS (IBM SPSS Statistics, Version 22.0. Armonk, NY: IBM Corp.) to study the effect of the variables on lipase production and on the conversion obtained in esterification reactions. Data were tested for homogeneity, submitted to one-way analysis of variance (ANOVA) and a pair-wise multiple comparison procedure (Tukey test) at a confidence level of $95 \%$.

\section{Results and discussion}

\subsection{Characterization of residues and evaluation of their effect on enzymes production}

The characterization of OCs and SBM are shown in Table 1. Significant differences of concentrations of protein, lipid, car- 

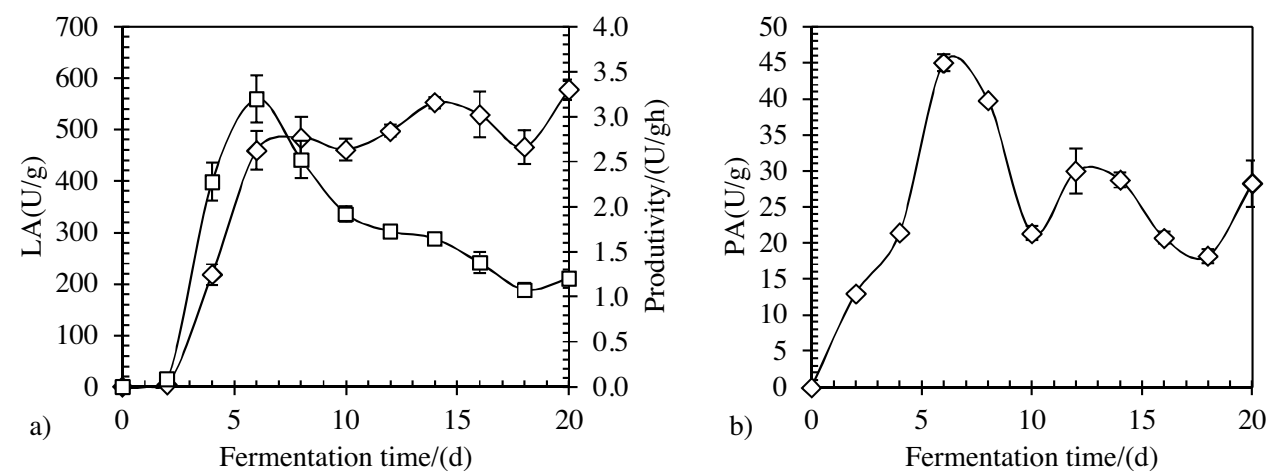

Fig. 4 - Profiles of (a) lipase activity (LA) $(\neg \sim)$, lipase productivity ( $\square-)$ and (b) protease activity (PA) over fermentation time. Values are the mean of two individual fermentations \pm standard deviation.

bohydrates, and other compounds, were found between the different OCs used. These residues were used for SSF to produce lipase by A. ibericus. Lipase and protease produced after 7 days of SSF were significantly dependent $(p<0.0001)$ on the OCs used (Table 1). SSF using PKOC presented higher lipase production following by SOC, but protease was not detected for PKOC, whereas for SOC a significant production was obtained.

In order to observe the relationship of residue components and enzyme production, PCA was performed involving the components of OCs that can affect the production of enzymes (ashes, proteins, cellulose, hemicellulose, lignin, carbohydrates, lipids): lipase and protease. This descriptive statistic tool allows grouping the original variables into fewer variables (principal components) that were used to carry out the representation. In this way, PCA allows to observe the main differences between the 9 agro-industrial wastes and their effect on lipase and protease production.

The 3 first principal components (PC) contained $87 \%$ of the total variation in results, indicating the close interrelation among OCs characteristics and enzymes production. The first principal component (PC1) described $48 \%$ of the original variance, the second principal component (PC2) explained $23 \%$ and the third principal component (PC3) explained $16 \%$ of the variation. Fig. 1 shows the biplot representation of variables and scores of OCs and SBM on the plane defined by PC1 and PC2. PC1 is well correlated positively with cellulose, lignin, hemicellulose and negatively with ashes, proteins and protease activity. This PC1 grouped the residues with a lignocellulosic nature, such as PKOC, GCOC, MOC and AOC, on the right side. In addition, PC1 grouped the residues with high protein content, such as SBM and SOC, on the left side. Thus, the residues with higher fibers content showed a lower protein content. Protease was correlated with the concentration of protein in OCs (Fig. 1). Since PKOC presents lower protein content, protease activity obtained was null, thus, in this substrate, the lipases formed are not degraded by proteases.

PC2 correlated well positively with lipase activity and negatively with carbohydrates. The OCs that achieved maximum lipase activity were PKOC and SOC that can be observed at the top of Fig. 1. The negative effect of carbohydrates on lipase production was clear. The inhibitory effect of carbohydrates on lipase production was also observed by Arora et al. (2015). The presence of carbohydrates can induce the production of other enzymes as exoglucanases (Hanif et al., 2004) and limit the production of lipases. In addition, glucose presents a repressing effect on lipase production (Dalmau et al., 2000). The lipids content had a lower weigh on PC2 showing a positive effect on lipase production. Some authors concluded that oil content increases lipase production (Gombert et al., 1999), as observed using SOC. However, the maximum lipase production was achieved by PKOC which has lower lipid content than other OCs, such as SOC. High lipids content above certain limits could inhibit the lipase production. In this sense, Damaso et al. (2008) observed a reduction of lipase production by Aspergillus niger with increasing olive oil addition to wheat bran, and at $12 \%$ of olive oil lipase activity was no longer detected. Chen et al. (1998) observed a cell lysis in Acinetobacter radioresistens at high concentrations of olive oil that reduced the lipase production.

$\mathrm{CaOC}$ (Brassica napus) and CrOC (Crambe abyssinica) are together in the left side of the plot (Fig. 1). These residues are generated after oil extraction from seed plants that are members of the same plant family (Brassicaceae), thus they have a similar composition. The same effect was observed between MOC and AOC. Both residues are obtained from seed oil extraction from Brazilian trees Carapa guianensis (Andiroba) and Acrocomia aculeata (Macaúba). The SBM is an outlier of the figure, insomuch as it is a substrate different to OCs, containing vestigial residual oil, high protein content and not being of lignocellulosic nature.

\subsection{Study of synergic effect of OCs on lipase production}

After screening OCs for lipase production by SSF, the residues that achieved a higher production were mixed to improve lipase activity. Mixtures of PKOC with two OCs, CrOC and SOC, were performed. Combinations of two OCs influenced significantly $(p<0.01)$ lipase production, where the use of PKOC + SOC led to a maximum production of $328 \pm 6 \mathrm{U} / \mathrm{g}$, corresponding to a 2.6-fold increase, compared to the value obtained on PKOC alone. Also, the mixture PKOC + CrOC presented improved yields, reaching $272 \pm 23 \mathrm{U} / \mathrm{g}$. The mixture of residues is attractive for the growth of microorganisms on SSF, since each residue may act differently as support matrix, nutrient source and as inducer for the production of enzymes (Edwinoliver et al., 2010). As can be observed, PKOC + SOC combination produced a synergic effect and improved lipase production. This effect may be due to an increase in the relative percentage of C18:n fatty acids (Lakshmi et al., 1999). Palm kernel oil has a low content of C18:n fatty acids, while sesame oil has a higher content in C18:n fatty acids (Ribeiro et al., 2016). Also, the mixture of both substrates may be supplemented and diluted by each other with the protein, ashes and lipids content from SOC and, with the hemicellulose from PKOC, improving the lipase production. 
Table 2 - Factors (moisture content (MC) and PKOC ratio (RPKOC), expressed as $g$ of PKOC per $g$ of total substrate), and assigned levels in a central composite design. Experimental and predicted values of lipase activity (LA) obtained. Values are the mean of triplicate analysis \pm standard deviation (SD).

\begin{tabular}{lllcl}
\hline Run & $\mathrm{MC} /(\mathrm{g} / \mathrm{g})$ & $\mathrm{RPKOC} /(\mathrm{g} / \mathrm{g})$ & Experimental LA $\pm \mathrm{SD} /(\mathrm{U} / \mathrm{g})$ & Predicted LA/(U/g) \\
\hline 1 & 0.5 & 0.25 & $313 \pm 16$ & 283 \\
2 & 0.5 & 0.75 & $122 \pm 22$ & 145 \\
3 & 0.7 & 0.25 & $55 \pm 7$ & 54 \\
4 & 0.7 & 0.75 & $69 \pm 25$ & 121 \\
5 & 0.4586 & 0.5 & $208 \pm 31$ & 217 \\
6 & 0.7414 & 0.1464 & $172 \pm 27$ & 38 \\
7 & 0.6 & 0.8536 & $198 \pm 16$ & 199 \\
8 & 0.6 & 0.5 & $377 \pm 31$ & 149 \\
9 & 0.6 & 0.5 & $330 \pm 15$ & 348 \\
10 & 0.6 & 0.5 & $336 \pm 11$ & 348 \\
11 & 0.6 & & & 348 \\
\hline
\end{tabular}

Using the best combination of OCs, an optimization study of MC and composition of PKOC and SOC in the substrate (RPKOC) mixture was performed to improve lipase yields. A central composite design was used and results are presented in Table 2. Lipase production was significantly affected $(p<0.05)$ by MC and RPKOC (Fig. 2a). In fact, high or low levels of MC would significantly affect the biosynthesis of the enzymes (Sun and Xu, 2008). Low MC levels reduce the solubility of nutrients contained in solid substrate (Mahadik et al., 2002; Pandey, 2003; Sun and Xu, 2008), resulting in hampered microbial growth (Pandey, 2003; Singhania et al., 2009). High MC levels decrease substrate porosity, reduce gas volume and exchange, leading to oxygen diffusion limitation in the substrate layer (Edwinoliver et al., 2010; Hamidi-Esfahani et al., 2004; Singhania et al., 2009; Sun and Xu, 2008) and the microbial growth decreases (Hamidi-Esfahani et al., 2004).

A polynomial equation, with the moisture content (MC) and the palm kernel oil cake ratio (RPKOC) as its independent variables, was fitted to experimental values of lipase activity (LA), as follows:

$$
\mathrm{LA}=-2929.5+11547.0 \mathrm{MC}-11007.0 \mathrm{MC}^{2}
$$

$$
+85.4 \text { RPKOC }-1387.7 \text { RPKOC }^{2}+2052.3 \mathrm{MC} . \mathrm{RPKOC}
$$

The analysis of variance indicated a satisfactory fitting of the equation to the experimental data, presenting a coefficient of determination $\left(R^{2}\right)$ of 0.932 . The variation of LA with MC and RPKOC was represented as response surface plot, using Statistica software (Fig. 2b). To set optimum SSF conditions, the Solver tool of Excel was used to maximize lipase production as given by Eq. (2). A MC of 0.57 (57\%) and a RPKOC of $0.45 \mathrm{~g} / \mathrm{g}$ were obtained, predicting a lipase production of $360 \mathrm{U} / \mathrm{g}$. Optimal conditions found were similar to MC and RPKOC used in previous experiments, leading to $10 \%$ improvement of lipase production. The result of optimum MC achieved was also similar to that found by Oliveira et al. (2016) using A. ibericus to produce lipase by SSF of olive pomace with wheat bran.

For certain substrates, the supplementation with a nitrogen source may be need to enhance lipase production, thus the effect of $\mathrm{NH}_{4} \mathrm{Cl}$ supplementation was studied. Increasing the $\mathrm{NH}_{4} \mathrm{Cl}$ level from 0 to $1 \%$ did not affect lipase production significantly (Tukey test), in spite of the $22 \%$ increase obtained at $1 \%$ (Fig. 3). Thus, in further experiments $1 \% \mathrm{NH}_{4} \mathrm{Cl}$ was added to the substrates for SSF. At higher levels of $\mathrm{NH}_{4} \mathrm{Cl}$ (above 3\%), the production was reduced (statistically significant), due to the possible inhibitory effect of $\mathrm{NH}_{4} \mathrm{Cl}$, as observed for other nitro- gen sources by Imandi et al. (2013) and Oliveira et al. (2015a), using urea and $\left(\mathrm{NH}_{4}\right)_{2} \mathrm{SO}_{4}$, respectively.

Finally, a time course profile of lipase production and its productivity was performed (Fig. 4). After 6 days, a lipase production of $460 \pm 38 \mathrm{U} / \mathrm{g}$ was obtained, and it was increasing till 20 days of fermentation, yielding $578 \pm 20 \mathrm{U} / \mathrm{g}$ (Fig. 4a). However, maximum productivity was obtained on the 6th day $(3.2 \pm 0.3 \mathrm{U} /(\mathrm{gh}))$. Contrary to lipase, protease activity reached its maximum of $45 \pm 1 \mathrm{U} / \mathrm{g}$ on the 6 th day and decreased to $28 \pm 3 \mathrm{U} / \mathrm{g}$, after 20 days of fermentation (Fig. $4 \mathrm{~b}$ ).

The time course profiles of lipase and productivity were similar to the obtained by Oliveira et al. (2015a), using A. ibericus on olive pomace with wheat bran. However, some authors found maximum lipase and productivity in a shorter time period, performing SSF at Erlenmeyer flasks level. Kamini et al. (1998) found a maximum lipase on the 3rd day, achieving $364 \mathrm{U} / \mathrm{g}$ and productivity of $5.1 \mathrm{U} /(\mathrm{g}$ h) of A. niger lipase by SSF of gingelly oil cake. Similarly, Mala et al. (2007) obtained a maximum lipase on the 3rd day, achieving $384 \mathrm{U} / \mathrm{g}$ and productivity of $5.3 \mathrm{U} /(\mathrm{gh})$ of A. niger lipase by SSF of gingelly oil cake mixed with wheat bran, observing an increment with the mixture of substrates. Edwinoliver et al. (2010) observed that SSF combining three substrates, wheat rawa, coconut oil cake and wheat bran, led to maximum production of $629 \mathrm{U} / \mathrm{g}$ on the 4th day, and a productivity of $6.6 \mathrm{U} /(\mathrm{g} \mathrm{h})$. Mahadik et al. (2002) obtained up to $300 \mathrm{U} / \mathrm{g}$ on the 5 th day and a productivity up to $2.5 \mathrm{U} /(\mathrm{g} \mathrm{h})$, using A. niger by SSF of wheat bran.

This work presents an interesting study of the influence of OCs composition on lipase production, and showed the great importance of performing SSF using two selected OCs based on its composition, at optimum MC to improve lipase production, in agreement with the literature (Pandey, 2003; Pandey et al., 2000; Singhania et al., 2009) and previous work (Oliveira et al., 2016, 2015a). In addition, the use of PKOC with SOC doubled A. ibericus lipase production, comparing to the obtained lipase using olive pomace with wheat bran (Oliveira et al., 2015a,b).

\subsection{Lipase activity in different substrates and application in esterification reactions}

\subsubsection{Lipolytic activity tested in different substrates}

The lipase produced at optimum SSF conditions was applied in hydrolysis reactions with different substrates. Fig. 5 presents results of lipase activity as affected by the TAGs used. Lipase was able to hydrolyze all TAGs used, presenting maximum activity on C4:0 and C8:0, reaching $58 \pm 2 \mathrm{U} / \mathrm{g}$ and $61 \pm 3 \mathrm{U} / \mathrm{g}$, respectively. A. ibericus lipase showed higher activity for short- 


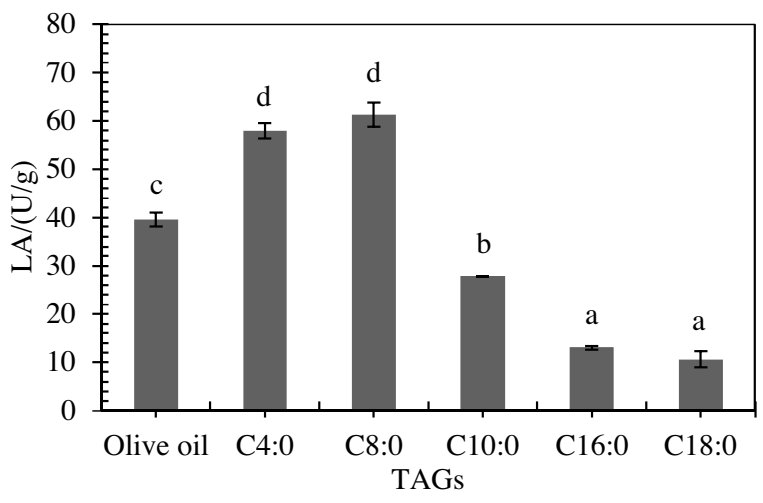

Fig. 5 - Lipase activity (LA) determined by titration method, using different triacylglycerols (TAGs) as substrates. Values are the mean of duplicate analyses \pm standard deviation. Means with the same letter do not differ significantly at $p>0.05$ (T-test).

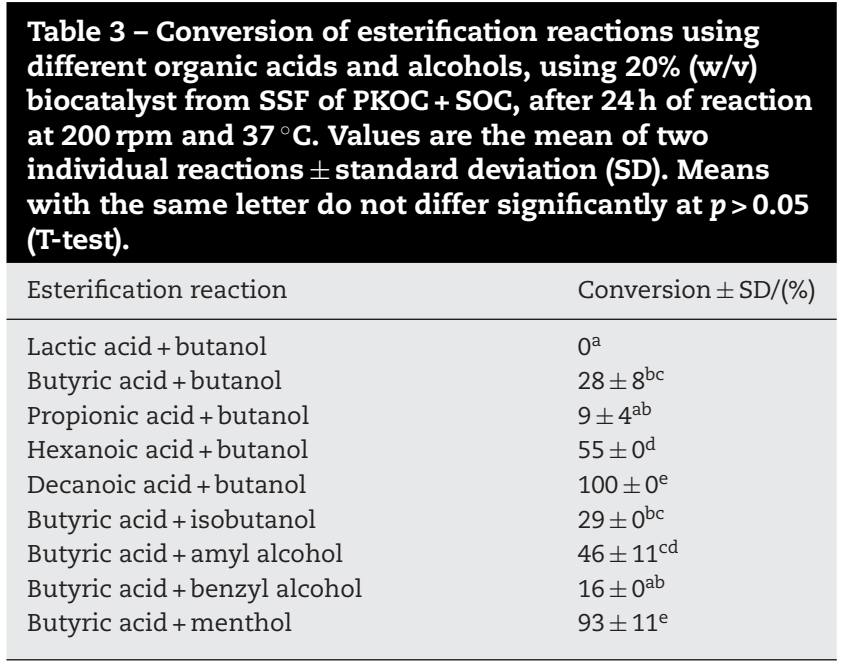

chain than for long-chain fatty acid esters, revealing high esterase activity (<8 carbon atoms of chain fatty acid). An intermediate lipase activity ( $40 \pm 1 \mathrm{U} / \mathrm{g})$ was observed using olive oil as substrate (Fig. 5). Olive oil is a mixture of TAGs with long-chain fatty acids (>95\%): around $72 \%$ oleic acid (18:1), $14 \%$ palmitic acid (16:0), 9\% linoleic acid (18:2) and 3\% stearic acid (18:0) (Kamal-Eldin and Andersson, 1997), evidencing activity of the lipase for natural long-chain fatty acids, as it was produced in SSF of substrates containing a relatively high percentage of C18:n fatty acids, mainly from SOC. Lipolytic activity for synthetic C16:0 and C18:0 was very low. Similarly, Gutarra et al. (2009) found higher lipolytic activities for C8:0 and C10:0, intermediate activities for olive oil and C16:0, and very low for C4:0 and C18:0, using Penicillium simplicissimum in SSF of babassu cake. These results of lipase activity obtained by titrimetric method using TAGs as substrates were significantly lower than that obtained by the spectrophotometric method using $p$-nitrophenyl butyrate.

\subsubsection{Esterification reactions catalyzed by lipase}

Lipase with high stability in organic solvents may allow its use in esterification reactions (Gilham and Lehner, 2005). Strategies to improve kinetics and yields of esterification reactions catalyzed by lipases may be achieved (Villeneuve, 2007). The optimization of reaction conditions such as substrate used, enzyme load, reaction time and buffering may increase the lipase-catalyzed production of aroma esters. Table 3 presents
Table 4 - Literature values of Log P of individual organic acids and alcohols.

\begin{tabular}{lrll} 
Organic acid & Log P & Alcohol & Log P \\
\hline Lactic acid & -0.72 & Butanol & 0.84 \\
Butyric acid & 0.79 & Isobutanol & 0.79 \\
Propionic acid & 0.33 & Amyl alcohol & 1.10 \\
Hexanoic acid & 1.92 & Benzyl alcohol & 1.10 \\
Decanoic acid & 4.09 & Menthol & 3.38 \\
\hline
\end{tabular}

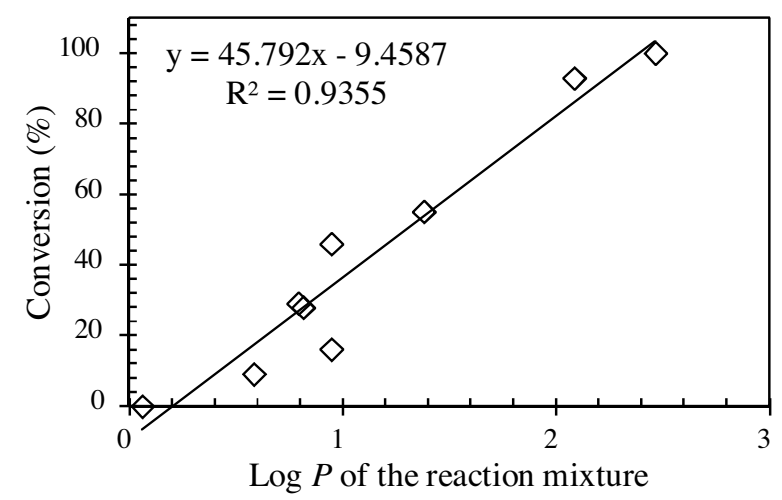

Fig. 6 - Results of conversion (Table 3) as a function of $\log P$ of the reaction mixture, and representation of a linear regression fitted to the experimental values.

the conversion of organic acids to esters in the esterification reaction combining different organic acids and alcohols. Maximum conversion (100\%) was observed for the combination of decanoic acid with butanol, leading to the production of butyl decanoate aroma ester. Also, butyric acid with menthol presented high conversion (93 $\pm 11 \%)$.

The polarity of the reaction mixture may affect lipase activity. Substrates with high polarity may inhibit enzyme activity (Sun et al., 2013), by damaging the water micro-layer in a vicinity of the lipase, which is necessary to keep the enzyme in its active conformation (Ben Salah et al., 2007; Bezbradica et al., 2007). The lower conversions using lactic acid, butyric acid and propionic acid were due to the high polarity of these substrates (Table 4). On the contrary, using decanoic acid with butanol and butyric acid with menthol, the conversion was higher since higher log $P$ values of decanoic acid and menthol contributed to the decreased polarity of the reaction mixture (Sun et al., 2013). Log P is defined as the logarithm of the partition coefficient of a substrate in the standard 1-octanol-water two-phase system (Dutra et al., 2008). The use of non-polar substrates for enzymatic esterification may increase conversion, by increasing $\log \mathrm{P}$ of the reaction mixture, as determined in numerous studies (Bezbradica et al., 2007; Vermue and Tramper, 1995). A linear correlation between log P of the reaction mixture (Table 4) and conversion (Table 3) was found, with a satisfactory coefficient of determination (Fig. 6). Therefore, the mixture of decanoic acid with butanol in esterification reactions was used in further studies.

From an economic perspective, achieving high conversion utilizing a low amount of enzyme in the reaction is important. Therefore, the effect of the biocatalyst load on esterification reaction of decanoic acid with butanol, for a $24 \mathrm{~h}$ reaction time, was studied. At least $10 \%(\mathrm{w} / \mathrm{v})$ of biocatalyst was needed to obtain a maximum conversion (100\%) (Table $5 a$ ). The use of $5 \%$ $(\mathrm{w} / \mathrm{v})$ of biocatalyst led to 5 -fold decrease in the conversion. Based on these results, a biocatalyst load of $10 \%(\mathrm{w} / \mathrm{v})$ was used in further experiments. 
Table 5 - Conversion in esterification reactions of decanoic acid with butanol at $200 \mathrm{rpm}$ and $37^{\circ} \mathrm{C}$, (a) using different

biocatalyst load, after $24 \mathrm{~h}$ of reaction; (b) over reaction time using $10 \%(\mathrm{w} / \mathrm{v}$ ) biocatalyst; and (c) using $5 \%$ (w/v) biocatalyst lyophilized in universal buffer at different $\mathrm{pH}$, after $24 \mathrm{~h}$ of reaction. Values are the mean of two individual

reactions \pm standard deviation (SD). Means with the same letter do not differ significantly at $p>0.05$ (T-test).

Conditions/conversion $\pm \mathrm{SD} /(\%)$

(a) Biocatalyst load/(\%, w/v)

Conversion $\pm \mathrm{SD} /(\%)$

(b) Reaction time/(h)

Conversion $\pm \mathrm{SD} /(\%)$

(c) Universal buffer $\mathrm{pH}$

Conversion $\pm \mathrm{SD} /(\%)$

$\begin{array}{ll}1 & 5 \\ 2 \pm 1^{\mathrm{a}} & 22 \pm 1^{\mathrm{b}} \\ 0 & 2 \\ 0^{\mathrm{a}} & 28 \pm 11^{\mathrm{b}} \\ 5 & 6 \\ 64 \pm 6^{\mathrm{a}} & 71 \pm 6^{\mathrm{ab}}\end{array}$

A time course profile of conversion over reaction time was performed, using $10 \%$ (w/v) of biocatalyst in the mixture of $5 \mathrm{~mL} \mathrm{1:1} \mathrm{(molar)} \mathrm{of} \mathrm{decanoic} \mathrm{acid} \mathrm{with} \mathrm{butanol.} \mathrm{As} \mathrm{presented}$ in Table $5 b$, the conversion increased gradually reaching maximum conversion (100\%) after $24 \mathrm{~h}$ reaction.

Since lyophilization of the enzyme together with salts has been shown to greatly improve the enzyme performance (Triantafyllou et al., 1997), leading to higher conversion, thus in these esterification reactions only $5 \%$ of the biocatalyst was used and it was possible to obtain the maximum conversion $(100 \%)$ with universal buffer at $\mathrm{pH}$ of 7 and 8 (Table $5 \mathrm{c}$ ). Salts may induce activation of lipase due to the polar environment constituted by the salt-bonded water surrounding the lipase, increasing enzyme flexibility (Jin et al., 2013). Also, the buffer $\mathrm{pH}$ used during the lyophilization of the biocatalyst seemed important. Zaks and Klibanov (1985) observed that the catalytic activity of lipase in the organic medium very much depends on the $\mathrm{pH}$ from which the enzyme was precipitated, with the maximum approximately coinciding with the $\mathrm{pH}$ optimum of the enzymatic activity in water. This effect is due to the fact that ionogenic groups of the enzyme acquire a certain ionization state in the aqueous solution of a given $\mathrm{pH}$. This ionization state (and the enzymatic activity corresponding to it) is retained in the solid state and in organic solvents (Zaks and Klibanov, 1988).

A. ibericus lipase was able to produce butyl decanoate ester. This aroma ester has relevant interest for food industry. Butyl decanoate ester is a colorless liquid with a characteristic odour of whiskey, and can be applied to products requiring a dairy product/creamy note, with a dosage of $7-35 \mathrm{ppm}$ in the finished product (Unitedint, 2016). The optimization process led to obtain maximum conversion, using $5 \%(\mathrm{w} / \mathrm{v})$ of biocatalyst lyophilized in universal buffer at $\mathrm{pH} 7$ or 8 for $24 \mathrm{~h}$ in the esterification reaction of decanoic acid with butanol, in a solvent-free system.

\section{Conclusion}

Agro-industrial residues and its combination used for SSF by A. ibericus led to different lipase yields. Mixing PKOC with SOC is a promising strategy to obtain high lipase yields while treating wastes. Optimizing SSF conditions, a final lipase production of $460 \pm 38 \mathrm{U} / \mathrm{g}$, and maximum productivity of $3.2 \pm 0.3 \mathrm{U} /(\mathrm{gh})$ were obtained after 6 days of fermentation. Lipase produced was effective to produce butyl decanoate ester in a solvent-free system, at optimum esterification reaction conditions.

The present work presents an environmental friendly strategy to naturally produce an aroma ester in a solvent-free system, with application in the food industry, while adding value to the agro-industrial residues.

\section{Acknowledgements}

Felisbela Oliveira acknowledges the financial support from FAPERJ $N^{\circ}$ 43/2013-Programa de Apoio ao DoutoradoSanduíche Reverso-2013, from Rio de Janeiro, Brazil and from the Portuguese Foundation for Science and Technology (FCT), through the grant SFRH/BD/87953/2012. José Manuel Salgado was supported by grant CEB/N2020 - INV/01/2016 from Project "BIOTECNORTE - Underpinning Biotechnology to foster the north of Portugal bioeconomy" (NORTE-01-0145FEDER-000004). This study was supported by the Portuguese Foundation for Science and Technology (FCT) under the scope of the strategic funding of UID/BIO/04469/2013 unit and COMPETE 2020 (POCI-01-0145-FEDER-006684) and BioTecNorte operation (NORTE-01-0145-FEDER-000004) funded by the European Regional Development Fund under the scope of Norte2020 - Programa Operacional Regional do Norte.

Carlos E. Souza and Verônica R.O.L. Peclat thank the financial support given by $\mathrm{CNPq}$ and CAPES from Brazil, respectively. Bernardo D. Ribeiro and Maria A.Z. Coelho thank the financial support given by CNPq and FAPERJ from Brazil.

\section{References}

Abrunhosa, L., Oliveira, F., Dantas, D., Gonçalves, C., Belo, I., 2013. Lipase production by Aspergillus ibericus using olive mill wastewater. Bioprocess Biosyst. Eng. 36, 285-291, http://dx.doi.org/10.1007/s00449-012-0783-4.

AOAC, 1995. Official Methods of Analysis of AOAC International, 16th ed. Association of Official Analytical Chemists.

Arora, M., Patel, J., Baser, I., Chhasatia, M.R., 2015. Effect of medium constituents on the growth and lipase production in Pseudomonas aeruginosa 2036. Int. J. Adv. Res. Biol. Sci. 2, 171-176.

Atimtay, A.T., Topal, H., 2004. Co-combustion of olive cake with lignite coal in a circulating fluidized bed. Fuel 83, 859-867, http://dx.doi.org/10.1016/j.fuel.2003.09.015.

Bano, Z., Shashirekha, M.N., Rajarathnam, S., 1993. Improvement of the bioconversion and biotransformation efficiencies of the oyster mushroom (Pleurotus sajor-caju) by supplementation of its rice straw substrate with oil seed cakes. Enzyme Microb. Technol. 15, 985-989, http://dx.doi.org/10.1016/0141-0229(93)90176-3.

Ben Salah, R., Ghamghui, H., Miled, N., Mejdoub, H., Gargouri, Y., 2007. Production of butyl acetate ester by lipase from novel strain of Rhizopus oryzae. J. Biosci. Bioeng. 103, 368-372, http://dx.doi.org/10.1263/jbb.103.368.

Bezbradica, D., Mijin, D., Šiler-Marinković, S., Knežević, Z., 2007. The effect of substrate polarity on the lipase-catalyzed synthesis of aroma esters in solvent-free systems. J. Mol. Catal. B Enzym. 45, 97-101, http://dx.doi.org/10.1016/j.molcatb.2006.12.003.

Castilho, L.R., Polato, C.M.S., Baruque, E.A., SantíAnna, J., Freire, D.M.G., 2000. Economic analysis of lipase production by Penicillium restrictum in solid-state and submerged 
fermentations. Biochem. Eng. J. 4, 239-247,

http://dx.doi.org/10.1016/S1369-703X(99)00052-2.

Charney, J., Tomarelli, R.M., 1947. A colorimetric method for the determination of the proteolytic activity of duodenal juice. J. Biol. Chem. 171, 501-505.

Chen, S.J., Cheng, C.Y., Chen, T.L., 1998. Production of an alkaline lipase by Acinetobacter radioresistens. J. Ferment. Bioeng. 86, 308-312, http://dx.doi.org/10.1016/S0922-338X(98)80135-9.

Couto, S.R., Sanromán, M.A., 2005. Application of solid-state fermentation to ligninolytic enzyme production. Biochem. Eng. J. 22, 211-219, http://dx.doi.org/10.1016/j.bej.2004.09.013.

Dalmau, E., Montesinos, J., Lotti, M., Casas, C., 2000. Effect of different carbon sources on lipase production by Candida rugosa. Enzyme Microb. Technol. 26, 657-663, http://dx.doi.org/10.1016/S0141-0229(00)00156-3.

Damaso, M.C.T., Passianoto, M.A., de Freitas, S.C., Freire, D.M.G., Lago, R.C.A., Couri, S., 2008. Utilization of agroindustrial residues for lipase production by solid-state fermentation. Braz. J. Microbiol. 39, 676-681, http://dx.doi.org/10.1590/S1517-83822008000400015.

Dutra, J.C.V., da C. Terzi, S., Bevilaqua, J.V., Damaso, M.C.T., Couri, S., Langone, M.A.P., Senna, L.F., 2008. Lipase production in solid-state fermentation monitoring biomass growth of Aspergillus niger using digital image processing. Appl. Biochem. Biotechnol. 147, 63-75, http://dx.doi.org/10.1007/s12010-007-8068-0.

Edwinoliver, N.G., Thirunavukarasu, K., Naidu, R.B., Gowthaman, M.K., Kambe, T.N., Kamini, N.R., 2010. Scale up of a novel tri-substrate fermentation for enhanced production of Aspergillus niger lipase for tallow hydrolysis. Bioresour. Technol. 101, 6791-6796,

http://dx.doi.org/10.1016/j.biortech.2010.03.091.

Freire, D.M., Teles, E.M., Bon, E.P., Sant' Anna, G.L., 1997. Lipase production by Penicillium restrictum in a bench-scale fermenter: effect of carbon and nitrogen nutrition, agitation, and aeration. Appl. Biochem. Biotechnol. 63-65, 409-421, http://dx.doi.org/10.1007/BF02920442.

Gilham, D., Lehner, R., 2005. Techniques to measure lipase and esterase activity in vitro. Methods 36, 139-147, http://dx.doi.org/10.1016/j.ymeth.2004.11.003.

Gombert, A.K., Pinto, A.L., Castilho, L.R., Freire, D.M.G., 1999. Lipase production by Penicillium restrictum in solid-state fermentation using babassu oil cake as substrate. Process Biochem. 35, 85-90, http://dx.doi.org/10.1016/S0032-9592(99)00036-9.

Gutarra, M.L.E., Godoy, M.G., Maugeri, F., Rodrigues, M.I., Freire, D.M.G., Castilho, L.R., 2009. Production of an acidic and thermostable lipase of the mesophilic fungus Penicillium simplicissimum by solid-state fermentation. Bioresour. Technol. 100, 5249-5254, http://dx.doi.org/10.1016/j.biortech.2008.08.050.

Hamidi-Esfahani, Z., Shojaosadati, S.A., Rinzema, A., 2004. Modelling of simultaneous effect of moisture and temperature on A. niger growth in solid-state fermentation. Biochem. Eng. J. 21, 265-272, http://dx.doi.org/10.1016/j.bej.2004.07.007.

Hanif, A., Yasmeen, A., Rajoka, M.I., 2004. Induction, production, repression, and de-repression of exoglucanase synthesis in Aspergillus niger. Bioresour. Technol. 94, 311-319, http://dx.doi.org/10.1016/j.biortech.2003.12.013.

IAL, 2005. Métodos químicos e físicos para análise de alimentos, 4th ed. Normas Analíticas do Instituto Adolfo Lutz, São Paulo.

Imandi, S.B., Karanam, S.K., Garapati, H.R., 2013. Use of Plackett-Burman design for rapid screening of nitrogen and carbon sources for the production of lipase in solid state fermentation by Yarrowia lipolytica from mustard oil cake (Brassica napus). Brazilian J. Microbiol. 44, 915-921, http://dx.doi.org/10.1590/S1517-83822013005000068.

Jin, Q., Jia, G., Wang, X., Li, C., 2013. Comparison of the salt-induced activation of Pseudomonas cepacia lipase in organic media by phosphate buffer and sodium sulfate. Chin. J. Catal. 34, 1224-1231, http://dx.doi.org/10.1016/S1872-2067(12)60558-0.
Joseph, B., Ramteke, P.W., Thomas, G., 2008. Cold active microbial lipases: some hot issues and recent developments. Biotechnol. Adv. 26, 457-470, http://dx.doi.org/10.1016/j.biotechadv.2008.05.003.

Kamal-Eldin, A., Andersson, R., 1997. A multivariate study of the correlation between tocopherol content and fatty acid composition in vegetable oils. J. Am. Oil Chem. Soc. 74, 375-380, http://dx.doi.org/10.1007/s11746-997-0093-1.

Kamini, N.R., Mala, J.G.S., Puvanakrishnan, R., 1998. Lipase production from Aspergillus niger by solid-state fermentation using gingelly oil cake. Process Biochem. 33, 505-511, http://dx.doi.org/10.1016/S0032-9592(98)00005-3.

Khan, T.A., Saxena, S.K., 1997. Integrated management of root knot nematode Meloidogyne javanica infecting tomato using organic materials and Paecilomyces lilacinus. Bioresour. Technol. 61, 247-250, http://dx.doi.org/10.1016/S0960-8524(97)00024-2.

Kota, K., Sridhar, P., 1999. Solid state cultivation of Streptomyces clavuligerus for cephamycin C production. Process Biochem. 34, 325-328, http://dx.doi.org/10.1016/S0032-9592(98)00078-8.

Lakshmi, B.S., Kangueane, P., Abraham, B., Pennathur, G., 1999. Effect of vegetable oils in the secretion of lipase from Candida rugosa (DSM 2031). Lett. Appl. Microbiol. 29, 66-70, http://dx.doi.org/10.1046/j.1365-2672.1999.00578.x.

Mahadik, N.D., Puntambekar, U.S., Bastawde, K.B., Khire, J.M., Gokhale, D.V., 2002. Production of acidic lipase by Aspergillus niger in solid state fermentation. Process Biochem. 38, 715-721, http://dx.doi.org/10.1016/S0032-9592(02)00194-2.

Mala, J.G.S., Edwinoliver, N.G., Kamini, N.R., Puvanakrishnan, R., 2007. Mixed substrate solid state fermentation for production and extraction of lipase from Aspergillus niger MTCC 2594. J. Gen. Appl. Microbiol. 53, 247-253, http://dx.doi.org/10.2323/jgam.53.247.

Mendez, M.H.M., Derivi, S.C.N., Rodrigues, M.C.R., Fernandes, M.L., Machado, R.L.D., 1985. Método de fibra detergente neutro modificado para amostras ricas em amido. Ciência Tecnol. Aliment. 5, 123-131.

Ohtsuki, T., Akiyama, J., Shimoyama, T., Yazaki, S.-I., Ui, S., Hirose, Y., Mimura, A., 2003. Increased production of antioxidative sesaminol glucosides from sesame oil cake through fermentation by Bacillus circulans strain YUS-2. Biosci. Biotechnol. Biochem. 67, 2304-2306, http://dx.doi.org/10.1271/bbb.67.2304.

Oliveira, F., Abrunhosa, L., Venâncio, A., Belo, I., Pérez-Rodríguez, N., Domínguez, J.M., 2015. Aspergillus ibericus lipase production by solid-state fermentation of olive pomace. In: Vilarinho, C., Castro, F., Russo, M. (Eds.), Wastes: Solutions, Treatments and Opportunities. Taylor \& Francis Group, London, pp. 195-201.

Oliveira, F., Venâncio, A., Belo, I., Pérez-Rodríguez, N., Domínguez, J.M., 2015. Scale-up of Aspergillus ibericus lipase production by solid-state fermentation. In: Vilarinho, C., Castro, F., Russo, M. (Eds.), Wastes: Solutions, Treatments and Opportunities. Taylor \& Francis Group, London, pp. 203-208.

Oliveira, F., Moreira, C., Salgado, J.M., Abrunhosa, L., Venâncio, A., Belo, I., 2016. Olive pomace valorization by Aspergillus species: lipase production using solid-state fermentation. J. Sci. Food Agric. 96, 3583-3589, http://dx.doi.org/10.1002/jsfa.7544.

Pandey, A., 2003. Solid-state fermentation. Biochem. Eng. J. 13, 81-84, http://dx.doi.org/10.1016/S1369-703X(02)00121-3.

Pandey, A., Soccol, C.R., Mitchell, D., 2000. New developments in solid state fermentation: I-bioprocesses and products. Process Biochem. 35, 1153-1169, http://dx.doi.org/10.1016/S0032-9592(00)00152-7.

Ramachandran, S., Singh, S.K., Larroche, C., Soccol, C.R., Pandey, A., 2007. Oil cakes and their biotechnological applications-a review. Bioresour. Technol. 98, 2000-2009, http://dx.doi.org/10.1016/j.biortech.2006.08.002.

Ribeiro, S.A.O., Nicacio, A.E., Zanqui, A.B., Biondo, P.B.F., de Abreu-Filho, B.A., Visentainer, J.V., Gomes, S.T.M., Matsushita, M., 2016. Improvements in the quality of sesame oil obtained by a green extraction method using enzymes. LWT-Food Sci. Technol. 65, 464-470, http://dx.doi.org/10.1016/j.lwt.2015.08.053. 
Salgado, J.M., Abrunhosa, L., Venâncio, A., Domínguez, J.M., Belo, I., 2014a. Screening of winery and olive mill wastes for lignocellulolytic enzyme production from Aspergillus species by solid-state fermentation. Biomass Convers. Biorefin. 4, 201-209, http://dx.doi.org/10.1007/s13399-013-0100-8.

Salgado, J.M., Abrunhosa, L., Venâncio, A., Domínguez, J.M., Belo, I., 2014b. Integrated use of residues from olive mill and winery for lipase production by solid state fermentation with Aspergillus sp. Appl. Biochem. Biotechnol. 172, 1832-1845, http://dx.doi.org/10.1007/s12010-013-0613-4.

Salihu, A., Alam, M.Z., AbdulKarim, M.I., Salleh, H.M., 2012. Lipase production: an insight in the utilization of renewable agricultural residues. Resour. Conserv. Recycl. 58, 36-44, http://dx.doi.org/10.1016/j.resconrec.2011.10.007.

Serra, R., Cabañes, F.J., Perrone, G., Castellá, G., Venâncio, A., Mulè, G., Kozakiewicz, Z., 2006. Aspergillus ibericus: a new species of section Nigri isolated from grapes. Mycologia 98, 295-306, http://dx.doi.org/10.3852/mycologia.98.2.295.

Singhania, R.R., Patel, A.K., Soccol, C.R., Pandey, A., 2009. Recent advances in solid-state fermentation. Biochem. Eng. J. 44, 13-18, http://dx.doi.org/10.1016/j.bej.2008.10.019.

Singhania, R.R., Soccol, C.R., Pandey, A., 2008. Application of tropical agro-industrial residues as substrate for solid-state fermentation processes. In: Pandey, A., Soccol, C.R., Larroche, C. (Eds.), Current Developments in Solid-State Fermentation. Springer, New Delhi, pp. 412-442, http://dx.doi.org/10.1007/978-0-387-75213-6_18.

Sircar, A., Sridhar, P., Das, P.K., 1998. Optimization of solid state medium for the production of clavulanic acid by Streptomyces clavuligerus. Process Biochem. 33, 283-289, http://dx.doi.org/10.1016/S0032-9592(97)00058-7.

Sun, J., Yu, B., Curran, P., Liu, S.-Q., 2013. Lipase-catalysed ester synthesis in solvent-free oil system: is it esterification or transesterification? Food Chem. 141, 2828-2832, http://dx.doi.org/10.1016/j.foodchem.2013.05.109.

Sun, S.Y., Xu, Y., 2008. Solid-state fermentation for whole-cell synthetic lipase production from Rhizopus chinensis and identification of the functional enzyme. Process Biochem. 43, 219-224, http://dx.doi.org/10.1016/j.procbio.2007.11.010.

Thomas, L., Larroche, C., Pandey, A., 2013. Current developments in solid-state fermentation. Biochem. Eng. J. 81, 146-161, http://dx.doi.org/10.1016/j.bej.2013.10.013.

Triantafyllou, A.O., Wehtje, E., Adlercreutz, P., Mattiasson, B., 1997. How do additives effect enzyme activity and stability in non-aqueous media? Biotechnol. Bioeng. 54, 67-76, http://dx.doi.org/10.1002/(SICI)1097-0290(19970405)54:1 $<67$ :AID-BIT8>3.0.CO;2-W.

Unitedint, 2016. United International Inc. URL http://www.unitedint.com/en/proshow.asp?id=405\&classid=41 (Accessed 4 December 2016).

Van Soest, P.J., 1963. Use of detergent in the analysis of fibrous feed I, preparation of fiber residues of low nitrogen. J. Assoc. Off. Agric. Chem. 46, 925-929.

Vermue, M.H., Tramper, J., 1995. Biocatalysis in non-conventional media: medium engineering aspects (technical report). Pure Appl. Chem. 67, 345-373, http://dx.doi.org/10.1351/pac199567020345.

Villeneuve, P., 2007. Lipases in lipophilization reactions. Biotechnol. Adv. 25, 515-536, http://dx.doi.org/10.1016/j.biotechadv.2007.06.001.

Zaks, A., Klibanov, A.M., 1985. Enzyme-catalyzed processes in organic solvents. Biochemistry 82, 3192-3196.

Zaks, A., Klibanov, A.M., 1988. Enzymatic catalysis in nonaqueous solvents. J. Biol. Chem. 263, 3194-3201. 